\title{
The Crown and Government Formation: Conventions, Practices, Customs, and Norms
}

\section{Philippe Lagassé*}

The Crown's role in government formation is poorly understood in Canada. As demonstrated by the confusion surrounding the Lieutenant Governor's duties in the aftermath of recent elections in British Columbia, New Brunswick, Prince Edward Island, and Newfoundland and Labrador, the functions of the Crown are misrepresented by politicians vying for power and misconstrued by commentators. These cases also suggest a degree of uncertainty about the Crown's powers within the vice-regal office themselves. There has been a regrettable tendency to exaggerate the Crown's involvement in government formation, which risks dragging the vice-regal representatives into the political arena or creating unrealistic expectations about the personal discretion they are able to exercise.

Misunderstandings about the Crown's place in government formation can be traced to three gaps in knowledge. The first is a vague comprehension of the foundational conventions of responsible government as they pertain to the Crown. While the conventions that surround the government's need to secure and hold the confidence of the elected house of the legislature are widely recognized, the conventions that frame the relationship between a first minister and the Crown are not. Second, there is confusion about what counts as a veritable constitutional convention. Conventions are too often conflated with other types of rules, notably practices, customs, and norms. Differentiating between these con- cepts helps us identify which constitutional rules firmly bind the Crown and which are more fluid and evolving. Thirdly, the lack of official explanations and transparency about the Crown's functions and constitutional activities makes it difficult to appreciate the rules that surround the institution. While some vice-regal offices have made efforts to better articulate their constitutional roles, there is a need for greater openness and explanation.

My aim in this article is to offer an analysis of the types of rules that surround the Crown and government formation in Canada. I begin the article with a discussion of the difference between constitutional convention, practice, custom, and norms. I then examine how the Crown's role in government formation are guided by these four types of rules. I conclude by recommending ways that vice-regal offices can better explain their functions and avoid confusion and controversy about their powers and personal discretion.

\section{Categorizing the rules}

Constitutional conventions serve a vital purpose in Canada's system of government. They regulate the interaction between powers of the state and ensure that essential constitutional principles, such as democracy, the rule of law, and the separation of powers, operate within and between institutions and offices. Although con- 
ventions have been described as the "morality of the constitution," this fails to capture their function today. Conventions are power distribution mechanisms. ${ }^{2}$ In some cases, conventions will grant authority; in others, they will constrain actors. For instance, these binding constitutional rules ensure that the Canadian executive has democratic legitimacy, through the confidence conventions, ${ }^{3}$ and that ministers are accountable to Parliament for the affairs of government, owing to the conventions of ministerial responsibility. ${ }^{4}$ Conventions also explain the Prime Minister's dominance over the executive and within Cabinet, ${ }^{5}$ as well as the duties and safeguards that protect certain offices of state, such as the independence of the Attorney General. ${ }^{6}$

Constitutional conventions can be contrasted with the law of the Constitution. ${ }^{7}$ Constitutional law is subject to enforcement by the courts. Conventions, on the other hand, are only subject to judicial identification, not enforcement. This means that courts can recognize the existence of conventions, and determine their scope and meaning, but that the onus to respect them lies with the actors that they are meant to bind. While this lack of judicial enforcement can lead to concerns about their strength and the ability of political actors to circumvent them, clear violations of convention are rare in Canada. This reflects the adaptable nature of convention. Conventions are flexible, which allows them to be slightly bent when necessary and to adapt to new circumstances. Their inherent elasticity is one reason conventions are not codified into law. Although conventions are often manipulated for partisan reasons, political actors rarely completely and publicly break them.

Stating that conventions are rarely violated may strike critics as an odd statement. It is not uncommon to hear accusations that politicians are violating convention. ${ }^{8}$ These charges, however, arguably reflect a misunderstanding of particular rules or mistakes about what counts as a veritable convention. In the latter case, the word 'convention' will be attached to another type of rule, one that does not meet the criteria for a constitutional convention. Specifically, conventions can be confused with three related, but distinct, kinds of rules: practices, customs, and norms. ${ }^{9}$ To differentiate them, it is necessary to outline the characteristics of constitutional conventions and how they differ from these other types.

As held by the Supreme Court of Canada, for a rule to be a constitutional convention, it must meet a test set out by Sir Ivor Jennings: first, the rule must have precedents; second, the actors involved must believe that they were bound by the rule (and hence, that the actors agreed on the rule); and third, the rule must exist for a reason. ${ }^{10}$ Among the rules that meet these criteria are that the Queen appoints the Governor General on the advice of the Prime Minister, and that the Governor General acts on the advice of the Prime Minister when appointing the other members of Cabinet. ${ }^{11}$ Rules that do not meet these criteria are not a constitutional convention, but something else (Table 1).

As Rodney Brazier has argued, one of these other categories of rules are practices. ${ }^{12}$ These are rules they may become conventions but are not quite there yet. Practices have a reason, usually grounded in political prudence or democratic ideals, and political actors propose and follow them with these reasons in mind. Yet, actors may not agree that they are bound by them, and there may be disagreement about the scope and application of the rule. As well, the precedents that support a practice tend to be inconsistent. Accordingly, practices are best seen as rules that are auditioning to become conventions. Certain practices will solidify over time and become conventions as actors agree about what they require and when they are binding. Others will be amended or adjusted, never gaining a solid enough foothold to achieve widespread agreement or force. Still others will be abandoned.

One example is the government's tabling of treaties before Parliament from 1926 to 1966, which was then abandoned by the government of Lester B. Pearson, then resumed under Prime Minister Stephen Harper. ${ }^{13}$ Another example is the current, inconsistently applied, practice of holding votes in the House of Commons when the government deploys the military overseas. ${ }^{14}$ These practices share a reason, involving the Commons in foreign policy decisions, but gov- 
Table 1: Rule characteristics

\begin{tabular}{|l|l|l|}
\hline \multicolumn{1}{|c|}{ Type of Rule } & \multicolumn{1}{c|}{ Present } & \multicolumn{1}{c|}{ Contested or weak } \\
\hline Constitutional Convention & $\begin{array}{l}\text { Precedents } \\
\text { Acceptance and agreement } \\
\text { Reasons }\end{array}$ & Ethical imperative \\
\hline Practice & Reasons & $\begin{array}{l}\text { Precedents } \\
\text { Acceptance and agreement } \\
\text { Ethical imperative }\end{array}$ \\
\hline Custom & Precedents \\
& Acceptance and agreement & $\begin{array}{l}\text { Reasons } \\
\text { Ethical imperative }\end{array}$ \\
\hline Norm & $\begin{array}{l}\text { Reasons } \\
\text { Ethical imperative }\end{array}$ & $\begin{array}{l}\text { Acceptance and agreement } \\
\text { Precedents }\end{array}$ \\
\hline
\end{tabular}

ernments have clarified that they are not binding, and their scope is the subject of regular debate between parties. ${ }^{15}$

Customs are another type of rule that can be confused with convention. ${ }^{16}$ In some cases, these traditions are antiquated conventions whose reasons no longer hold or apply, yet they are generally respected out of habit. In other cases, customs simply reflect established ways of doing things, with no connection to a rule that rose to the level of convention. Customs are thus characterized by their precedents and the tendency of actors to believe that these traditions should be honoured. What they lack are clear or solid reasons. One such custom is the rule that the Monarch or their representative will not enter the lower house of Parliament. This tradition dates back to a time when the Commons needed to protect itself and its members from the Crown's interference. While this tradition is still followed at the federal level, its rationale is no longer salient. Customs are followed because 'this is just how we do things,' which means that they are usually respected but can be questioned, adapted, or disregarded when required.

Norms are a final category of rule. ${ }^{17}$ These are morally-binding rules of proper conduct.
They serve to define what is acceptable behaviour in a constitutional context, including which actions are necessary to uphold fundamental principles. To use a sports analogy, norms refer to the imperative to play the game fairly and ethically. ${ }^{18}$ They refer to actors' willingness to respect both the letter and the spirit of the Constitution. In this sense, norms are a type of meta-rule that ensure laws and other rules are followed properly. Norms are vital for a properly functioning democracy, since even the most detailed and powerful laws and conventions can be manipulated by ill-intentioned actors. Indeed, given the prominent role unwritten rules play in most constitutional systems, norms help to ensure that actors behave with fairness and honour when exercising their powers and authorities. The importance of norms is hinted at by the title of 'Honourable' that ministers, and of 'Right Honourable' that prime ministers and governors general, are granted. We expect our highest officeholders to exercise their powers and authorities honourably. Indeed, the proper functioning of our system depends on it.

Canada's 2008 prorogation controversy provides a useful illustration of the distinction between conventions and norms. By convention, the Governor General prorogues Parliament on 
the advice of the Prime Minister. Unlike dissolution, there are few precedents to support the argument that Crown in Canada can refuse advice to prorogue, except in the "most exceptional circumstances". ${ }^{19}$ When the Governor General accepted Prime Minister Harper's advice to prorogue Parliament in 2008 to avoid a vote of nonconfidence, the two actors were therefore acting in accordance with convention. What the Prime Minister arguably failed to do, however, was act fairly and honourably. ${ }^{20}$ According to critics, the Prime Minister abused his authority for partisan ends, undermining the right of the Commons to exercise its judgment over his government. ${ }^{21}$

Defenders of the Prime Minister, on the other hand, point out that the opposition parties were acting contrary to another norm, namely that coalitions should not be formed by parties lacking a plurality of seats unless their intent to form a coalition was clearly stated during a general election. ${ }^{22}$ These different interpretations further highlight that norms are often contested and that they lack the agreement that characterize conventions. ${ }^{23}$ Similarly, the precedents attached to a norm are not always evident and those engaged in a normative disagreement will point to different precedents to support their view. Hence, Harper's defenders pointed out that prorogation had never been refused by the Governor General, even in controversial circumstances, ${ }^{24}$ and that coalitions were not a common practice at the federal level, while his critics noted that prorogation should not be used to avoid votes of non-confidence. ${ }^{25}$

Similar distinctions apply to fixed election date legislation in Canada. The federal Parliament and provincial legislatures have passed laws that set a fixed date for dissolution. These statutes were meant to discourage first ministers from calling elections when it best suits their partisan interests. ${ }^{26}$ The existence of these laws, however, does not create a convention that first ministers must respect the fixed date, as was found in Conacher $v$ Canada (Prime Minister). ${ }^{27}$ Legislatures can still be dissolved earlier, at the request of the first minister. Instead, in the interests of fairness, the law implies that legislatures should not be dissolved before the fixed date, unless there is a good reason to so, such as a loss of confidence or when political actors believe that voters should be given a chance to pronounce themselves. ${ }^{28}$ As with prorogation, however, the fairness and propriety of calling an early election will often be in the eye of the beholder. Relevant precedents, moreover, will be a source of debate, with the fixed dates being respected in some cases and first ministers calling early elections in others. ${ }^{29}$

Differentiating between these types of rules provides greater clarity about what is required by the Constitution, what is currently considered politically prudent or democratically preferable, what is traditionally done, and what should be done in the interests of fairness, honour, and the spirit of the Constitution (Table 2). Applying these categories to the Crown's role in government formation, it will now be argued, improves our understanding of the different types of rules that surround vice-regal representatives in that process.

\section{Government formation rules and the Crown}

Contemporary government formation involves a mix of conventions, practices, customs, and norms. Unfortunately, heated partisan rhetoric, bad faith actors, and confused media commentary has muddied understandings of the rules in each category and their interaction. Re-establishing precision within and between these categories is therefore worthwhile.

\section{Conventions}

The conventions that guide the Crown's role in government formation go to the core of the monarchical function in the Canadian Constitution. The reasons, precedents, and acceptance of these conventions are deeply rooted for the most part.

The first set of relevant conventions focus on the Crown and advice:

The first minister takes responsibility for the acts of the Crown, and the Crown almost always acts on the advice of the first minister, as a result. 
Table 2: Rule essences and examples

\begin{tabular}{|l|l|l|}
\hline \multicolumn{1}{|c|}{ Type of Rule } & \multicolumn{1}{|c|}{ Summary } & \multicolumn{1}{c|}{ Example } \\
\hline Constitutional Convention & $\begin{array}{l}\text { What must be done, } \\
\text { constitutionally. }\end{array}$ & $\begin{array}{l}\text { The government should hold } \\
\text { the confidence of the elected } \\
\text { House. }\end{array}$ \\
\hline Practice & What is currently being done. & $\begin{array}{l}\text { The Commons votes on military } \\
\text { deployments. }\end{array}$ \\
\hline Custom & What is traditionally done. & $\begin{array}{l}\text { The Crown does not enter the } \\
\text { Commons. }\end{array}$ \\
\hline Norms & What one should do, morally. & $\begin{array}{l}\text { The Crown's powers should not } \\
\text { be abused for partisan ends. }\end{array}$ \\
\hline
\end{tabular}

Regarding government formation, there are two decisions where the Crown retains personal discretion: 1) the acceptance or rejection of a recommendation to dissolve the legislature; 2) the appointment and dismissal of a first minister.

The historical rationale underlying this convention was that the Crown "can do no wrong", hence a minister would need to take responsibility and be held accountable for the Crown's action. ${ }^{30}$ Today, the rationale further includes the principle that the Crown is not involved in governing, and that the first minister who heads the government must therefore be responsible and accountable for all acts of government and the Crown. ${ }^{31}$ Most importantly, the democratic principle is such that the Crown should act on the advice of a first minister who commands, or is seeking to secure, the confidence of the elected house. ${ }^{32}$

The precedents supporting this rule are wellestablished; cases where a Governor General or Lieutenant Governor has acted contrary to formal advice are quite rare and idiosyncratic. ${ }^{33}$ On appointments, prorogation, and other exercises of Crown power that require formal advice from the first minister, the precedents are clear: the Crown acts on the advice and the first minister takes responsibility for the decision. ${ }^{34}$ The absence of notable violations of this rule further demonstrate that the Crown and first ministers agree and understand that they are bound by it.

The dissolution of the legislature is an exception to the rule that the Crown acts on the advice of the first minister, but the nature of that exception require careful elaboration. Dissolution is granted on the recommendation of the first minister; the Crown can decline this request when there is an alternative government that can hope to secure the confidence of the elected house. However, the discretion that the Crown has to refuse a dissolution does not mean that the vice-regal representative has the constitutional authority to dissolve the legislature without the first minister's recommendation. Put differently, the Crown's right to refuse a request to dissolve the legislature does not imply that the Crown has the authority to trigger a dissolution on its own. The underlying rule that the Crown acts through the first minister remains. Suggestions that the choice to dissolve the legislature belongs to the Crown, as was hinted at following the last election in British Columbia, ${ }^{35}$ are incorrect.

The appointment and dismissal of the first minister is a second exception. In most cases where the Crown must appoint a new first minister, the choice will be relatively straightforward: 
the appointee will be the leader of the party who is best placed to hold the confidence of the elected house. When a governing party changes leader, the Crown will appoint the party's new leader. Similarly, if a first minister is incapacitated or dies in office, an order of succession among Cabinet ministers, ${ }^{36}$ or a decision among ministers or the party caucus, will determine who should be appointed as a replacement. The Crown's discretion will only come into play when a first minister resigns and it is unclear who can hold the confidence of the house, or in very exceptional cases when a first minister has resigned or been dismissed, an obvious successor has not been identified, and a new first minister must be appointed. ${ }^{37}$ In these cases, the Crown has a duty to appoint the individual they believe is best suited to bring stability and order to the affairs of government. While the Crown may take recommendations from the outgoing first minister, other ministers, senior civil servants, or personal advisors, the vice-regal representative will be acting with discretion in these extreme cases.

Dismissals of a first minister are the ultimate exercise of discretion by the Crown and should therefore only be considered in truly exceptional cases, such as when a first minister is incapacitated, acting in clear violation of the Constitution, undermining the stability and legitimacy of the government, or involved in criminality. ${ }^{38}$ Most of the time, a first minister will feel pressured to resign before the Crown is forced to dismiss them, but vice-regal discretion remains here. Precedents from Canada in the $19^{\text {th }}$ Century, the possibility of Lieutenant Governor David Lam dismissing British Columbia Premier Vander Zalm in 1991, ${ }^{39}$ and the 1975 dismissal of Prime Minister Gough Whitlam by Governor General Sir John Kerr in Australia highlight the continuing pertinence of this exceptional authority. ${ }^{40}$

Three related conventions reinforce the first set:

There must be a first minister to advise the Crown; the Crown's first duty is therefore to ensure that there is a first minister to proffer advice.

A first minister remains in office until the Crown accepts their resignation or they are dismissed by the Crown.
If the Crown refuses to act on the formal advice of their first minister, the first minister should resign or be dismissed.

Since the Crown almost always acts on the advice of a first minister who takes responsibility for the acts of the Crown, it follows that there should always be a first minister in place to advise the Crown. ${ }^{41}$ The Crown must therefore appoint a first minister when there is a vacancy. Indeed, except in cases involving deaths, unanticipated resignations, or dismissals, an obvious successor will usually be identified beforehand and the time between two successive first ministers is kept to a minimum. The relevant precedents here are negative ones: there are no instance of a contemporary Canadian federal or provincial government being without a first minister for a significant amount of time. The absence of interregnums between first ministerial tenures, moreover, demonstrates that the relevant actors agree and understand that there must be a first minister.

The duty to have a first minister to advise the Crown further explains one of the most misunderstood aspects of government formation and transition: that an incumbent first minister has the right to meet the legislature to secure its confidence following an election, regardless of the results. This right reflects the legal reality that first ministers remain in office until they resign or are dismissed, ${ }^{42}$ an arrangement that ensures the Crown is never without a first minister. Normally, a first minister who clearly cannot secure confidence will resign following an election. Yet, when the election has produced a hung Parliament and the incumbent might be able to negotiate an agreement with another party, the first minister can stay on until they lose a formal confidence vote. The recent case of Premier Brian Gallant's effort to stay in power after New Brunswick's 2019 election is an example. ${ }^{43}$ Equally important, there may be cases where no party can secure confidence. In these instances, the incumbent first minister remains in place and could consider recommending a dissolution.

While it might be argued that the Crown should appoint the leader of the party that has won the most seats following an election, this is not what the rules dictate. Instead, the Crown 
will wait until the incumbent first minister resigns, either shortly after the election or following a vote of no confidence. In the implausible case that an incumbent first minister who has no chance of securing confidence refuses to meet the legislature following an election, the Crown can dismiss them and appoint a first minister who will. Insofar as dismissal is a power of last resort, however, the Crown should almost always wait for the incumbent first minister to resign first.

Given that the relationship between the Crown and the first minister rests on the principle that the former acts on the advice of the latter, Canadian convention dictates that a first minister should resign or be dismissed if the Crown rejects their advice. This rule is necessary to ensure that the first minister takes responsibility for all acts of the Crown, and if they cannot, then another first minister must be appointed who can. Indeed, in the absence of this rule, viceregal representatives would be able to exercise a veto power over the affairs of government, which is counter to the foundations of responsible government. ${ }^{44}$

The existence of this rule does not mean that there cannot be negotiations between a first minister and the Crown. ${ }^{45}$ The Crown may deliberately delay the acceptance of advice, as Michaëlle Jean did when she agreed to grant Prime Minister Harper a short prorogation of Parliament. ${ }^{46}$ A first minister can also withdraw advice if the Crown signals that it will be rejected. But when a first minister insists, the Crown must either accept the advice or be prepared to name a new first minister ${ }^{47}$ Attaching this consequence to a refusal of advice acts as check on vice-regals, since there will be significant scrutiny if the Crown compels the resignation of a first minister if said first minister has not formally lost the confidence of the legislature. ${ }^{48}$ The precedents supporting this rule found in the resignation of first ministers whose recommendation to dissolve the legislature has been refused. The Crown's refusal leads to their resignation. As discussed below, a vote of no confidence is not a sufficient condition for a first minister to resign, but a clear and formal refusal of advice by the Crown should be. Equally telling, there are few evident cases of a Canadian first minister or vice-regal officers publicly disagreeing with one another about an act of the Crown. There may be rumours of disagreements and negotiations behind the scenes, but these are settled before a decision is formally announced. ${ }^{49}$

Another convention that governs the Crown and government formation is the one most would consider supreme. However, it is important to appreciate the nuances that surround it:

The first minister should hold the confidence of the elected house or be aiming to secure confidence.

Parliamentary democracy demands that the head of government command the confidence of the elected house of the legislature. This is the reason behind this rule. When appointing a first minister, the Crown will therefore name the individual who is likeliest to secure confidence. Yet there are certain caveats here. Above all, the loss of confidence does not mean that a first minister will necessarily resign. Instead, a first minister will typically request a dissolution. When such a request is accepted, the Crown allows the electorate to pronounce itself and grants the first minister a chance to regain confidence under new legislature. When a request to dissolve the legislature is refused, the Crown believes that another party leader can secure confidence, even if this has yet to be formally demonstrated when the appointment is made. Given the uncertainty that surrounds confidence, particularly in hung Parliaments, practices and customs have developed that guide when dissolution should be refused, as will be discussed below. In terms of the confidence rule itself, however, the key point is that the Crown's role is circumscribed. As with the first convention that was discussed, the Crown's functions are to determine whether a dissolution is warranted when confidence is withheld or withdrawn, and if not, to appoint the individual who is likeliest to secure it. ${ }^{50}$

The precedents attending to this rule are well-established. First ministers who lose a confidence vote are usually granted a dissolution. A recent example is the 2011 election, which took 
place after a vote of no confidence in Prime Minister Harper's government. Harper remained first minister throughout the election and his party was re-elected with a majority of seats. By contrast, when Christie Clark lost a vote of confidence following the 2017 election in British Columbia, she requested a dissolution and was refused. The Lieutenant Governor appointed John Horgan, the leader of the New Democratic Party, who had negotiated a confidence and supply agreement with the Green Party. Although Clark made a number of statements that created confusion about the Lieutenant Governor's role, the Crown acted within the limits circumscribed by convention. ${ }^{51}$

In sum, the conventions that pertain to the Crown and government formation are few and largely focused on the relationship between first ministers and vice-regal representatives. Arguably, what is most notable about these conventions is how they circumscribe the Crown's role. Rather than making the Crown a prominent part of the government formation process, they ensure that vice-regal representatives largely act as guardians of stable and legitimate government.

\section{Practices}

Practices serve an important function. While not rising to the level of convention, they establish parameters that help actors navigate the processes of government formation. For the Crown in particular, practices offer useful guidelines for vice-regal representatives in the potentially contentious settings that follow the election of a hung Parliament. Unlike conventions, however, uncertainty and debate about precedents and what the rules stipulate, and disagreements about whether they are binding, make them malleable. Indeed, practices can bend quite a bit, depending on the personalities involved.

A first practice relates to transitions of power:

When an incumbent first minister announces their resignation, the Crown will commission the leader of another party to form a government. During the transition period that follows, the incoming first minister will be titled 'first minister-designate.'
This practice developed in the twentieth century for administrative reasons. ${ }^{52}$ In order to give new first ministers a chance to organize their cabinet and policy priorities, and to give civil servants more time to prepare for the incoming ministry, the Crown began commissioning new first ministers to form a government before the incumbent formally resigns and the new ministry was sworn. The title of 'designate' is given to the incoming first minister to indicate that they have been commissioned by the Crown to form a government, but they are not yet first minister. Outside of vice-regal offices, however, the title of designate is being bestowed before the Crown has formally commissioned the new first minister. ${ }^{53}$ This suggests that the practice may evolve such that the Crown's commission is taken as a given.

During the transition period between governments, the incumbent ministry continues to exercise formal authority and they would be responsible for dealing with any crises or emergencies. ${ }^{54}$ The first minister designate and their transition team do not have authority to govern yet and should not be issuing directives to the civil service. Yet, not everyone accepts these boundaries. As seen during the transition from the Liberal to the Conservative government in Ontario following the 2018 election, members of Doug Ford's transition team appeared to be issuing directives before the new Premier was sworn in, and Ontario's Secretary to the Cabinet seems to have accepted their right to do so. ${ }^{55}$ This suggests that the practice may go beyond simply allowing for a smooth transition; it may evolve to give new governments a say over policy before they hold formal authority. Since the constitutional propriety of only having one first minister at a time responsible for the affairs of government is significant, however, what occurred in Ontario may be an anomaly tied to strong-willed partisans and pliant civil servants.

A second practice deals with the limitations on government decision-making during elections and hung Parliaments:

Ministers are bound by a principle of restraint during elections and should not make decisions that would unduly bind another government; 
incumbent governments who are not re-elected with a majority of seats will be bound by this principle until they secure the confidence of the legislature.

Known colloquially as the 'caretaker convention', this rule is founded on the idea that governing authority should be constrained when a parliament has been dissolved and voters are deciding the composition of the next legislature. While the government retains the power to address emergencies and manage the routine affairs of the executive, ministers should not make decisions that would be difficult or impossible for an alternative ministry to reverse. When a governing party is re-elected with a majority of seats in the legislature, the principle of restraint is lifted. Similarly, a government that is newly appointed following an election is not bound by the principle, regardless of the composition of the legislature, since they are assumed to be able to secure confidence if the Crown has appointed their leader the first minister. An incumbent government that is re-elected without a majority of seats, however, will be bound by the principle of restraint until they have won a vote of confidence. If an incumbent first minister announces that they will resign in light of an election result, they will also be bound by this principle during the period when the incoming government prepares its transition to power. ${ }^{56}$

Ministers are expected to accept that they are bound by the principle of restraint and senior civil servants will assist with the interpretation of what counts as routine matters of government. ${ }^{57}$ The first minister, however, retains the judgment to determine which decisions are permissible. During a period of restraint, the Crown will still act according to the advice of the first minister. But vice-regal representatives are in a stronger negotiating position in these cases. ${ }^{58}$ This is especially true when the incumbent government's ability to secure confidence is unclear, or when a first minister has announced their resignation and a new party leader is commissioned to form a government. In these situations, the Crown can request that the advice be delayed until confidence has been demonstrated. ${ }^{59}$ Inappropriate advice from a first minister who has already announced their resignation, notably with respect to appointments, can be rejected. ${ }^{60}$

The principle of restraint remains a practice in Canada at this time. The first minister's ability to determine its scope and application has arguably prevented it from becoming a convention. Yet, with the publication of guidelines outlining how the principle of restraint applies, and as the rule becomes a routine part of election planning by senior civil servants, sufficient precedents and the agreement necessary for this practice to solidify into convention may materialize.

Another practice relates to the Crown's interactions with parties during a hung Parliament:

The Crown does not involve itself in negotiations between political parties following elections that results in a hung Parliament; it is for the parties in the legislature to determine who governs, how confidence can be maintained, and whether the legislature is viable.

Several reasons underpin this practice. Above all, as will be discussed below under norms, the Crown is expected to remain neutral and nonpartisan, and to keep a sufficient distance from political bargaining between parties. ${ }^{61}$ This distance is meant to shield the Crown from impressions that a vice-regal representative is partial to one party. Equally important, this practice leaves it with political parties to determine who and how confidence will be maintained in a hung Parliament, and whether it will be possible to make the legislature work effectively despite the absence of a majority party. Here again, keeping the Crown away from these discussions serves to protect its neutrality and minimizes instances when vice-regal representatives will need to personally judge whether a government can hold confidence or a legislature is viable. Following the 2017 election in British Columbia, for example, the Lieutenant Governor kept her distance while the New Democrats and Greens negotiated their confidence and supply agreement, and she accepted John Horgan's assurances that the legislature would be viable under a New Democratic government, despite concerns about who would serve as Speaker and how they might need to vote to preserve confidence in the government. ${ }^{62}$ 
While the importance of keeping the Crown neutral and non-partisan is widely accepted, the logic of keeping vice-regal representatives out of post-election negotiations may not be. It might be argued that the Crown has a greater role to play here, acting as a facilitator or mediator between the parties. Advocates of this position might also argue that the Crown could remain neutral while helping the parties negotiate a stable governing arrangement. Similarly, it could be argued that the Crown should help parties find a way to make the legislature work after a tight election. ${ }^{63}$ Thus far, however, it would seem that vice-regal offices prefer the cautious approach of keeping the Crown away from discussions between parties. There are also few recent precedents of the Crown acting as a mediator. Yet, until the boundaries of the Crown's role are better articulated and accepted, this practice will remain below the threshold of a convention.

Two other practices related to government formation are more contentious:

Formal votes in the elected house are the proper test of whether or not a government holds confidence; comments and agreements made by opposition parties outside of the legislature are not sufficient indicators that the government has lost confidence.

The Crown can urge a first minister to demonstrate they still hold confidence when doubts arise; if a first minister is purposefully avoiding the legislature for an extended period of time to avoid a vote of no confidence, the Crown can warn them that they might be dismissed.

Relying on formal votes in the elected house to determine whether a government holds or has lost confidence rests on two reasons. First, the legislature as an institution and independent corporate body expresses itself through its formal procedures, not pledges or comments made by a portion of legislators outside of the chamber. The dignity of the legislature demands that it speak for itself according to its own rules; subsets of the legislature should not pretend to speak for it, no matter how accurately they may be echoing its views as a collective body. Second, prudence cautions against predicting how the legislature will act. Regardless of how confident political actors are about what will happen when a legislature sits, surprising and unexpected events do happen. Accordingly, this practice encourages the Crown to reply on formal votes alone when ascertaining whether or not a first minister hold confidence.

As one might expect, those hoping to make a government fall may have a different view about whether a formal vote is the only indication that confidence has been lost. For opposition parties, a clear intent to withdraw confidence from the government and form a new ministry should influence the Crown. In 2008, for instance, supporters of this view argued that the Governor General was not bound to follow the Prime Minister's advice to prorogue since the coalition to displace the Conservatives held the majority of seats in the House of Commons and declared an intent to withdraw confidence in Harper's government. ${ }^{64}$

Constitutional scholars have also argued that vice-regal representatives can consider other factors than formal votes of no confidence when judging whether they are bound by a first minister's advice, especially if the advice given serves to prevent the legislature from expressing itself. ${ }^{65}$ Defenders of formal votes, however, argue that relying on comments outside of the legislature undermines constitutional conventions related to advice, notably in terms of when the Crown can legitimately reject it. ${ }^{66}$ Indeed, abandoning this practice could see the Crown compelling the resignation of a government that has not formally lost confidence. The events of 2008, moreover, highlight the danger of relying on the promises of parties when trying to guess how the legislature will act when it meets. In the end, the coalition vying to replace the Harper government fell apart in the short period during which Parliament was prorogued, leading observers to conclude that the Governor General made a prudent decision. ${ }^{67}$

Since votes in the legislature are the most reliable test of confidence, current practice further allows the Crown to encourage first ministers to meet the elected house when serious doubt exists about whether they still hold confidence. This is where comments made outside of the legislature 
have a part to play. If opposition parties declare that they are committed to making the government fall and forming a new ministry, the Crown is within its rights to request that the first minister meet the legislature in short order. ${ }^{68}$

In cases where a government is refusing the meet the legislature, thereby undermining the confidence convention, the Crown can warn the first minister that they might be dismissed. The reason behind this rule is a powerful one: democratic principles demand that government be regularly held to account by the legislature and first minister should demonstrate that they hold confidence. However, there are few known precedents to back this rule and there is a lack of agreement about whether the Crown should threaten dismissal, save for the most exceptional of cases. As a result, this rule relies on reasons alone, making it a practice rather than a convention. The willingness of a vice-regal representative to issue such a warning will likely depend on the personality of the office-holder, their interpretation of the first minister's intentions, and their understanding of their role.

The practices surrounding the Crown and government formation are few but significant. They provide the Crown with guidelines to navigate potentially difficult situations that arise during transitions and hung Parliaments. Because they are subject to varying perspectives, and insofar as the precedents that underlie them are lacking or contested, they lack the force of conventions. Their application can therefore vary and be challenged.

\section{Customs}

Customs are a third type of rule that shapes government formation. While they lack solid reasons, they exert notable influence over the actors owing to their acceptance and agreement. Since they are long-standing rules, they tend to have a solid grounding in precedent. Indeed, precedent gives these rules their strength, in spite of the lack of a firm rationale. It must be reiterated, however, that customs are not convention. As a result, actors may choose to act contrary to these rules while still respecting the Constitution.
A first custom that pertains to government formation is one that is most often confused with convention, causing debate and consternation when it is not followed:

The party that carries the most seats during an election will usually serve as the government.

When a party carries a majority of seats during an election, there is no doubt that their leader will serve as first minister. Even if that majority is slim, the confidence convention and party discipline ensure that the leader of the party with a majority of seats will either form government or continue serving as first minister if they are the incumbent. When an election produces a hung Parliament, this custom remains fairly influential in Canada, particularly if one party's seat count is substantially larger than the others. Although these concepts do not fit well within a parliamentary democracy, the leader with the most seats is often held to have "won" the election, and media reports will often proclaim the party that has the most seats will govern as a minority. ${ }^{69}$ In most cases, the opposition parties will agree with this interpretation.

The limitations of this rule are exposed when an election produces a tight result, with two parties carrying a comparable number of seats. When the party with the second largest number of seats can cooperate with the third or fourth largest number, and they together have a majority, the custom that the party with the most seats should govern can be disregarded. Of course, this will often lead the largest party to protest and question the legitimacy of a smaller party governing, citing the idea of 'winners' and 'losers.' As seen in Ontario in 1985 and in British Columbia in 2017, however, hung Parliaments are not composed of winners and losers, but of potential partners who can negotiate agreements that allow smaller parties to govern. The tradition that the party with the most seats governs is not binding during hung Parliaments and has been set aside when the situation warrants it.

A second custom addresses when a request for dissolution should be granted: 
The Crown should not refuse a request to dissolve the legislature if more than six months has passed since an election.

Tradition holds that a first minister should be granted a dissolution upon request if sufficient time has passed since the last election. Sufficient time is often described as a period of six months or less. The thinking here is that, regardless of the composition of the legislature and the ability of another party to hold confidence, the electorate should have an opportunity to express itself rather than change governments within a single Parliament. This timeframe is supported by precedent, such as the dissolution of Parliament under the short-lived Joe Clark government, and is not the subject of significant controversy. Regardless, the reason behind this rule is shaky. ${ }^{70}$ Six months is an arbitrary number. It might be difficult to defend this cut-off in cases where the first minister had not recalled the legislature for a long period after the election or votes of no confidence had been avoided by various means. Moreover, there may be instances where a policy announcement or legislation introduced after six months since an election prompts opposition parties to organize themselves to displace the government. The Crown should judge the merits of their case based on the particularities of the situation when deciding whether a dissolution should be granted. While a six-month window may be appropriate in most circumstances, the Crown is not bound by this traditional timeframe.

A third custom touches upon the Crown's interactions with party leaders following an election that yields a hung Parliament:

The Crown should avoid numerous private meetings with party leaders when it is unclear who will be able to hold confidence after an election.

In keeping with the practice that the Crown should not serve as a mediator between parties, and the norm that the Crown should be seen as neutral and non-partisan, vice-regal representatives should only meet with party leaders if it truly necessary when it is unclear who will be able to secure the confidence of the legislature.
Partisan politicians can spin or misrepresent what was said during a private meeting with a vice-regal representative. Leaders can twist what the Crown might say in private for partisan ends. Efforts by the Crown to correct what was said can backfire and be read as biased. Simply put, the risks to the Crown's semblance of neutrality increase when a vice-regal representative agrees to meet with party leaders behind closed doors during tense post-election periods. Accordingly, vice-regal representatives have traditionally tried to minimize their interactions with party leaders in these situations.

The precedents surrounding this rule, however, are mixed and party leaders can push to meet with the Crown if they feel it serves their interests. Opposition parties who have negotiated a coalition or confidence and supply agreement, moreover, will want to show the Crown that they can hold confidence and that a request to dissolve the legislature before they have a chance to govern should be refused. The reasons behind this rule, furthermore, are open to critique. Perceptions of the Crown's neutrality and non-partisanship are not necessarily undermined by meeting with party leaders, and vice-regal offices are able to correct misrepresentations of what was said by issuing press releases. Indeed, observers have called on vice-regal offices to be more open and transparent as a matter of course; providing summaries of meetings with party leaders would be a step in that direction. ${ }^{71}$ Ultimately, it is for vice-regal offices to assess whether they are comfortable moving away from this tradition.

The customs that surround government formation are useful guides to how things are usually done. Yet the reasons behind these rules are not always solid and can clash with atypical situations and new expectations. Consequently, vice-regal representatives can choose to abandon these customs based on the particular circumstances they face.

\section{Norms}

Norms are the final set of rules to be considered. In many ways, they can be considered the most important. These morally-binding rules ensure that formal constitutional authority is exercised 
honourably and in keeping with fundamental constitutional principles. When norms are violated, the Constitution and affairs of government cannot operate properly, and the health of Canada's institutions is undermined. Unfortunately, except for evident cases, political actors may disagree about what norms demand and precedents are not always a useful guide when determining what is proper conduct.

A first norm addresses how the Sovereign and her vice-regal representatives should act:

The Crown should be, and be seen to be, neutral and non-partisan.

As an apolitical head of state, the Queen and her representatives must be above partisan politics and remain neutral in their dealings with politicians and constitutional questions. The legitimacy of these offices in modern democracies depends on their acting as guardians of the Constitution. If the Crown is seen to be insufficiently neutral or favourable to one party or ideological persuasion, its decisions can be called into question and the institution may be weakened. Accordingly, vice-regal representatives must do everything they can to act neutrally and to be seen as be non-partisan.

Regrettably, certain conventions and practices make it difficult for the Crown to avoid perceptions of partisanship. Having vice-regal representatives read partisan throne speeches, for instance, demands that the Crown speak in politically charged terms. ${ }^{72}$ Canadian governments have appointed former politicians to viceregal offices, which paints the office-holder with a partisan hue, whether justified or not. Political actors who are frustrated with a vice-regal decision can accuse the office-holder of bias. ${ }^{73}$ Poorly chosen words spoken by vice-regals can be misinterpreted by those looking for partisan leanings. In light of these challenges, vice-regal representatives must reiterate their neutrality when it is questioned and ensure that they do not allow themselves to be manipulated by partisans. This is especially important during postelection periods when political contentiousness is heightened.
A second norm pertains with the Crown's dealings with the first minister:

The Crown should encourage first ministers to exercise their powers honourably.

First ministers are partisan politicians. They struggle to gain the leadership of their parties, to win the most seats during general elections, and to hold onto power once they have obtained it. They face political opponents who are equally determined. The temptation to bend the rules, to do what it takes to win or survive, can be significant. Occasionally, this can lead the first minister to abuse their constitutional authority or use it in a dishonourable fashion. The severity of these abuses will vary. Such an abuse may be minor and defended as a fair use of the political advantages afforded the first minister, such as calling an election when an opposition party has just named a new leader. ${ }^{74}$ It may be notable but not especially severe; Harper's 2008 prorogation would arguably qualify here. But, it may also be quite problematic and evident. Using prorogation to force a "no deal" Brexit in the United Kingdom would be an example. ${ }^{75}$ Although these actions can be undertaken while respecting constitutional convention, and indeed thanks to convention, they are ethically dubious.

As the guardian of the Constitution, the Crown has a duty to discourage a first minister from acting dishonourably, particularly when formal advice is involved. Vice-regal representatives can attempt to change the first minister's mind, delay a decision to allow a cooling-off period, or tell the head of government that their actions are unbecoming of the minister of the Crown. ${ }^{76}$ As long as the first minister is acting within the rules of convention, however, viceregal representatives must accept their advice, unless they are prepared to compel the first minister to resign. Constitutionally, first ministers are responsible for unethical decisions and can be held to account for them.

Finally, norms must be relied upon to deal with veritable institutional crises:

In an emergency, the Crown may need to act contrary to the convention to protect democracy and the rule of law. 
While the Crown is constrained by convention when dealing with a first minister who is acting dishonourably, necessity dictates that the Crown prevent genuinely unconstitutional acts by the first minister, even if this involves temporarily setting aside convention. ${ }^{77}$ Were a first minister to refuse to accept their dismissal, order the armed forces to interfere with the democratic process or the legislature, or attempt to remove a Governor General without cause, the Crown could be forced to act independently. In nearly all cases, the legislature, the courts, or police should be permitted to deal with the problem first. If they are unable to do so, and the threat to democracy and the rule of law is sufficient, the Crown would have a duty to act. As an example, this might involve using the Crown's supreme military command authority to countermand a directive from the Prime Minister to the armed forces. The exact form of an exceptional action to guard democracy and the rule of law would depend on the circumstances, and there will always be a risk that the Crown's actions will be considered illegitimate or premature. But the Crown's normative duty to protect these principles is a critical feature of Canada's constitutional monarchy. ${ }^{78}$

\section{Conclusion}

The rules that surround the Crown and government formation are not obvious, especially to the non-specialist observer. While this analysis has offered an assessment of the relevant conventions, practices, customs, and norms, academic work cannot substitute for official descriptions and explanations of vice-regal roles and functions. Likewise, vice-regal offices and officeholders themselves would benefit from greater clarity regarding their place in the process of government formation. To this end, it would be beneficial for all vice-regal offices to prepare and publish guidelines that explain the Crown's constitutional powers and responsibilities. As well, vice-regal offices should be as transparent as possible about how the Crown performs its constitutional roles and functions.

The Office of the Lieutenant Governor of Ontario provides the best example of how vice- regal offices should explain their constitutional roles and activities. ${ }^{79}$ The Office's website details how the Crown's powers are exercised and in what context. Press releases provided by the Office also provide thorough explanations of the procedures followed during transitions, including the sequence of events that occur and how these reflect relevant government formation rules. ${ }^{80}$ At a minimum, these practices should be emulated across Canada.

Yet these measures are unlikely to be sufficient. Ultimately, it may be necessary to publish cabinet manuals, as has been done in New Zealand and the United Kingdom. If done in consultation with all parties in the legislature, a codification and categorization of the rules could fill the gaps in knowledge that surround government formation and the Crown's role in the process. As recent provincial elections demonstrate, better understanding of these rules is sorely needed.

\section{Endnotes}

* Associate Professor and Barton Chair, Norman Paterson School of International Affairs, Carleton University.

1 See AV Dicey, Introduction to the Law of the Constitution, 9 $^{\text {th }}$ Edition (London: Macmillan, 1939) at 417.

2 See James Mahoney \& Kathleen Thelen, "A Theory of Gradual Institutional Change" in James Mahoney \& Kathleen Thelen, eds, Explaining Institutional Change: Ambiguity, Agency, and Power (Cambridge: Cambridge University Press, 2010) 1.

3 See Eugene A Forsey \& GC Eglinton, “The Question of Confidence in Responsible Government" in Christian Leuprecht \& Peter H Russell, eds, Essential Readings in Canadian Constitutional Politics (North York: University of Toronto Press, 2011) 33. Forsey and Eglinton prepared the study in 1985 for the Special Committee on the Reform of the House of Commons.

4 See Geoffrey Marshall, Constitutional Conventions: The Rules and Forms of Political Accountability (Oxford: Clarendon, 1984) 54-79. 
5 See Philippe Lagassé, “The Crown and Prime Ministerial Power" (2016) 39:2 Can Parliamentary Rev 17.

6 See Craig Forcese, "LAffaire SNC-Lavalin: The Public Law Principles" (9 February 2019), online (blog): Public Law Blog <craigforcese.squarespace. com/public_law_blog/>.

7 See Anne Twomey, The Veiled Sceptre: Reserve Powers of Heads of State in Westminster Systems (Cambridge: Cambridge University Press, 2018) 23-30.

8 See e.g. concerns about violations of the 'caretaker convention' in Bruce M Hicks “These Were Unconstitutional Negotiations”, National Post (6 October 2015), online: <nationalpost. com/opinion/bruce-m-hicks-these-wereunconstitutional-negotiations $>$.

9 For a different typology centered on types of conventions, see Andrew Heard, Canadian Constitutional Conventions: The Marriage of Law and Politics, 2nd ed (Don Mills, ON: Oxford University Press, 2014).

10 See Reference Re Resolution to Amend the Constitution, [1981] 1 SCR 753 at 888, (sub nom Reference Re Amendment of the Constitution of Canada (Nos 1, 2 and 3)) 125 DLR (3d) 1 citing Sir Ivor Jennings, The Law of the Constitution, 5th ed (London: University of London Press, 1959) at 136.

11 Canada, Privy Council Office, Open and Accountable Government (Ottawa: Privy Council Office, 27 November 2015) Annex F.

12 See Rodney Brazier, "The Non-Legal Constitution: Thoughts on Convention, Practice and Principle" (1992) 43:3 N Ir Leg Q 262.

13 See Joanna Harrington, "Redressing the Democratic Deficit in Treaty Law Making: (Re-) Establishing a Role for Parliament" (2005) 50 McGill LJ 456 at 476-477; See generally Global Affairs Canada, "Policy on Tabling of Treaties in Parliament" (last modified 3 March 2014), online: Global Affairs Canada <treaty-accord.gc.ca/ procedures.aspx?lang=eng $>$.

14 See Philippe Lagassé, "Parliament and the War Prerogative in the United Kingdom and Canada: Explaining Variations in Institutional Change and Legislative Control" (2017) 70:2 Parliamentary Affairs 280.

15 See Philippe Lagassé, “The Constitutional Politics of Parliament's Role in International Policy" in Adam Chapnick \& Christopher J Kukucha, eds, The Harper Era in Canadian Foreign Policy: Parliament, Politics, and Canada's Global Posture (Vancouver: UBC Press, 2016) 56.
16 See Andrew Heard, "Constitutional Conventions and Parliament” (2005) 28:2 Can Parliamentary Rev 19 at 20.

17 See Neil S Siegel, "Political Norms, Constitutional Conventions, and President Donald Trump" (2018) 93:1 Ind LJ 177.

18 See Richard A Posner, "Social Norms and the Law: An Economic Approach" (1997) 87:2 American Economic Rev 365 at 365.

19 See Nicholas A MacDonald \& James WJ Bowden "No Discretion: On Prorogation and the Governor General" (2011) 34:1 Can Parliamentary Rev 7 at 12.

20 See Johannes Wheeldon "Prorogation as Constitutional Harm” (2011) 34:2 Can Parliamentary Rev 69.

21 See Andrew Heard, “The Governor General's Suspension of Parliament: Duty Done or a Perilous Precedent?” in Peter H Russell \& Lorne Sossin, eds, Parliamentary Democracy in Crisis (Toronto: University of Toronto Press, 2009.) 47 at 53-55.

22 See Rainer Knopff \& Dave Snow, “Harper's New Rules' for Government Formation: Fact or Fiction?" (2013) 36:1 Can Parliamentary Rev 18.

23 See Josh Chafetz \& David E Pozen, "How Constitutional Norms Break Down” (2018) 65:6 UCLA L Rev 1430.

24 See MacDonald and Bowden, supra note 19 at 12.

25 See Andrew Heard, "The Reserve Powers of the Crown: The 2008 Prorogation in Hindsight" in Jennifer Smith \& D Michael Jackson, eds, The Evolving Canadian Crown (Montreal \& Kingston: McGill-Queen's University Press, 2012) 87 at 94-95.

26 See Philippe Lagassé, "Institutional Change, Permanent Campaigning, and Canada's Fixed Election Date Law," in Alex Marland, Thierry Giasson \& Anna Lennox Esselment, eds, Permanent Campaigning in Canada (Vancouver: UBC Press, 2017) 167 at 171-172.

27 Conacher v. Canada (Prime Minister), 2010 FCA 131 at paras 5-6.

28 See Lagassé, "Institutional Change", supra note 26.

29 See James WJ Bowden, Reining in the Crown's Authority over Dissolution: The Fixed-Term Parliaments of the United Kingdom Act versus Fixed-Date Election Laws in Canada (MA Thesis, Carleton University, Carleton University, 2018) [unpublished].

30 Forsey \& Eglinton, supra note 3, Part II.

31 See Norman Ward, ed, Dawson's The Government of Canada, 6th ed (Toronto: University of Toronto Press, 1987) at 189.

32 Forsey \& Eglinton, supra note 3, Part II. 
33 See Twomey, supra note 7 at 44-114.

34 See Ward, supra note 31 at 173-194.

35 See Gary Mason, "On the Verge of Being Dethroned, Christy Clark's BC Liberals Seek Atonement", Globe and Mail (19 June 2017), online: $<$ www.theglobeandmail.com/news/britishcolumbia/dethroned-christy-clarks-bc-liberalsseek-atonement/article35384518/>.

36 See Chris Hannay, "Who Acts for Trudeau If He is Unable to Do His Job?", Globe and Mail (16 January 2017), online: <www.theglobeandmail.com/news/ politics/politics-briefing/article33631344/>.

37 See Vernon Bogdanor, The Monarchy and the Constitution (Oxford: Clarendon, 1995) at 84-112.

38 See Ward, supra note 31 at 189.

39 Douglas Todd\&KellySinoski “DavidLamObituary”, Vancouver Sun (22 November 2010), online: $<$ vancouversun.com/news/staff-blogs/davidlam-obituary>.

40 See Paul Kelly \& Troy Bramston, The Dismissal in the Queen's Name: A Groundbreaking New History (Melbourne: Penguin Books, 2016).

41 See Ward, supra note 31 at 183, 190-191.

42 See Philippe Lagassé, "Still the Premier" (28 September 2018), online (blog) In Defence of Westminster <lagassep.com/>.

43 See Elizabeth Fraser “'I Have a Duty”: Brian Gallant Won't Try For People's Alliance Deal", CBC News (1 October 2018), online: <www.cbc.ca/news/ canada/new-brunswick/brian-gallant-blainehiggs-election-1.4845121>.

44 See Alpheus Todd, Parliamentary Government in the British Colonies (London: Longsman, Green and Co, 1894) at 12-13.

45 See Twomey, supra note 7 at 44-114; Ward, supra note 31 at 186-189. Heard's discussion of when advice has been rejected points to negotiations as well, rather than formal rejection. See Heard, "Reserve Powers", supra note 25 at 89-90.

46 See Twomey, supra note 7 at 598-603.

47 See Ward, supra note 31 at 189-191.

48 See Bogdanor, supra note 37 at 66; Heard, Canadian Constitutional Conventions, supra note 9 at 43.

49 See Twomey, supra note 7 at 44-114; Ward, supra note 31 at 189.

50 In some cases, the Crown should also be aware that confidence can be regained, especially if a vote of no confidence was lost owing to procedural missteps or opposition tactics.

51 See Barbara Messamore, “Christy Clark's Indiscreet Remarks Risked Dragging Lieutenant Governor Into Controversy", National Post (7 July 2017), online: <nationalpost.com/opinion/ barbara-messamore-christy-clarks-indiscreetremarks-risked-dragging-lieutenant-governorinto-controversy>.

52 See references to the Prime Minister-designate in Canada, Privy Council Office, Manual of Official Procedure of the Government of Canada (Ottawa: Privy Council Office, 1968).

53 See e.g. the attribution of the designate title on the night of an election in Althia Raj "Jason Kenney is Now Premier-Designate of Alberta. What Does that Mean for the Trans Mountain Pipeline?", Huffington Post (16 April 2019), online: <www. huffingtonpost.ca/2019/04/16/jason-kenneyjustin-trudeau-transmountain_a_23712908/>.

54 Philippe Lagassé, "Clarifying the Caretaker Convention" (9 October 2015), online: Policy Options <policyoptions.irpp.org/2015/10/09/ clarifying-the-caretaker-convention/ $>$.

55 Memorandum from Cabinet Secretary Steve Orsini to Deputy Ministers and CAOs (18 June 2018) "Additional Expenditure Restrictions", online: Government of Ontario <www.ontario.ca/ page/news-secretary $>$. The memo was notable for copying the Premier-Designate's Chief of Staff, Dean French.

56 Privy Council Office, "Guidelines on the Conduct of Ministers, Ministers of State, Exempt Staff and Public Servants During an Election" (2015, last modified 8 December 2017), online: Government of Canada <www.canada.ca/en/privy-council/ services/publications/guidelines-conductministers-state-exempt-staff-public-servantselection.html>.

57 Ibid.

58 See Twomey, supra note 7 at 502-549.

59 See Ward, supra note 31 at 183-184. Resignations involving the selection a new party leader may be more complicated.

60 See the case of Lord Aberdeen and Prime Minister Tupper in Ward, supra note 31 at 190.

61 See UK, Cabinet Office, Cabinet Manual (London: Cabinet Office, 2011), s 2.9.

62 See Rob Shaw \& Richard Zussman, A Matter of Confidence: The Inside Story of the Political Battle for BC (Vancouver: Heritage, 2018), at 186-206.

63 For a discussion of how the Crown can serve as a mediator in certain cases, see Ward, supra note 31 at 184-185.

64 See Patrick J Monahan, “The Constitutional Role of the Governor General" in Smith \& Jackson, supra note 25,73

65 . Ibid.

66 See Robert E Hawkins, “Inefficient Efficiency': The Use of Vice-Regal Reserve Powers," in D 
Michael Jackson \& Philippe Lagassé, eds, Canada and the Crown: Essays on Constitutional Monarchy (Montreal \& Kingston: McGill-Queen's University Press, 2013) 101.

67 Eric Adams, "The Constitutionality of Prorogation" (2008) 18:1 Const Forum Const 17 at 19.

68 See Twomey supra note 7 at 582.

69 See Hugo Cyr, "On the Formation of Government" (2017) 22:1 Rev Const Stud 103 at 104-105.

70 In a pseudonymous letter to The Times in 1950, the King's Private Secretary, Sir Alan Lascelles, offers three factors that can influence the decision to refuse a request to dissolve Parliament. The letter and the debate surrounding it are analysed in Twomey, supra note 7 at 374-377.

71 See Lorne Sossin \& Adam Dodek, "When Silence Isn't Golden: Constitutional Convention, Constitutional Culture, and the Governor General" in Russell \& Sossin. supra note 21, 91.

72 See Richard Berthelsen, "The Speech from the Throne and the Dignity of the Crown," in Jackson \& Lagassé, supra note $65,161$.

73 See e.g. the case in Newfoundland and Labrador of Progressive Conservative Ches Crosbie accusing Lieutenant Governor Judy Foote of partisan bias following the province's 2019 election. Foote had been a federal Liberal Cabinet minister prior to her appointment: Ryan Cooke "Judy Foote Denies Partisanship After Crosbie Levels Accusations on Election Night", CBC News (17 May 2019), online: <www.cbc.ca/news/canada/ newfoundland-labrador/ches-crosbie-slams-balljudy-foote-1.5139743>.

74 See the example of Prime Minister Jean Chrétien requesting a dissolution of Parliament shortly after Stockwell Day won the leadership of the Canadian Alliance in 2000.

75 See Sam Fowles, "Can the Prime Minister Prorogue Parliament to Deliver a No Deal Brexit?" (10 June 2019), online (blog): UK Constitutional Law Association Blog <ukconstitutionallaw. org/2019/06/10/sam-fowles-can-the-primeminister-prorogue-parliament-to-deliver-a-nodeal-brexit/>.

76 See Ward, supra note 31 at 186-191.

77 See Twomey, supra note 7 at 13-15, 691-730.

78 See Frank MacKinnon, The Crown in Canada (Calgary: McClelland and Stewart West, 1976) at 122-135.

79 Office of the Lieutenant Governor of Ontario, "Constitutional Role", online: Lieutenant Governor of Ontario <www.lgontario.ca/en/constitutionalrole\#appointment-installation $>$.

80 See Office of the Lieutenant Governor of Ontario, "Media Advisory: Lieutenant Governor to Preside at Swearing-In of New Premier and Executive Council of Ontario" (27 June 2018), online: Lieutenant Governor of Ontario <www.lgontario. $\mathrm{ca} / \mathrm{en} / 2018 / 06 / 27 /$ media-advisory-lieutenantgovernor-to-preside-at-swearing-in-of-newpremier-and-executive-council-of-ontario/>. 
